\title{
PENERAPAN METODE PEMBELAJARAN TEAM QUIZ DALAM MENINGKATKAN MOTIVASI DAN HASIL BELAJAR KOGNITIF PESERTA DIDIK PADA MATA PELAJARAN FIQIH MATERI MAKANAN DAN MINUMAN HALAL DAN HARAM
}

\author{
Rohimah Tulsahidah ${ }^{1)}$ \\ 1) MTs Atta'zhimiyah, Jl. Holis Blk No. 448 Kelurahan Cigondewah \\ Kidul Kecamatan Bandung Kulon Kota Bandung \\ Email: rohimahsyahidah@gmail.com
}

\begin{abstract}
The purpose of this research is to know the implementation of team quiz learning method, to know the difference of motivation and cognitive learning outcomes among students are using team quiz method with students are using conventional method, and to know the learners' responses to the application of team quiz learning method.The approach used to quantitative approaches that's quasi experimental method form nonequivalent control group design. Based on the results of research that the implementation of learning Fiqh by using team quiz method includes preliminary activities, core and cover. The average value of experimental learning motivation 77.08 while the mean of learning control class motivation 59,92, the difference's significant, the values 6,65>1,96, then HO rejected and Ha accepted. The mean pretest grade of the experimental class 51.62 and the posttest average score of 83.62,

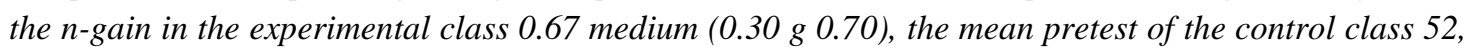
57 and the posttest average of 66.48, $n$-gain $0.29 \mathrm{low}(0.30 \mathrm{~g} 0.70)$. obtained a significant difference, the value of 5.47> 1.96, then HO rejected and Ha accepted. Student responses to the application of team quiz learning method is very good category, obtained an average percentage of $81.67 \%$.

Keywords:

Team quiz, learning motivation, cognitive learning outcomes.
\end{abstract}

\begin{abstract}
Abstrak : Tujuan penelitian ini yaitu untuk mengetahui penerapan metode pembelajaran team quiz, untuk mengetahui perbedaan motivasi dan hasil belajar kognitif antara peserta didik yang menggunakan metode team quiz dengan peserta didik yang menggunakan metode konvensional, serta untuk mengetahui tanggapan peserta didik terhadap penerapan metode pembelajaran team quiz. Pendekatan yang digunakan adalah pendekatan kuantitatif, dengan metode quasi eksperimen bentuk nonequivalent control group design. Berdasarkan hasil penelitian bahwa pelaksanaan pembelajaran Fiqih dengan menggunakan metode team quiz meliputi kegiatan pendahuluan, inti dan penutup. Nilai rata-rata motivasi belajar kelas eksperimen 77,08 sedangkan nilai rata-rata motivasi belajar kelas kontrol 59,92, diperoleh perbedaan yang signifikan, nilai $\mathrm{Z}_{\text {hitung }}>\mathrm{Z}_{\alpha}$ yaitu 6,65 >1,96, maka $\mathrm{H}_{0}$ ditolak dan $\mathrm{H}_{\mathrm{a}}$ diterima. Nilai rata-rata pretest kelas eksperimen 51,62 dan nilai rata-rata posttest 83,62, n-gain pada kelas eksperimen 0,67 berkategori sedang $(0,30<\mathrm{g} \geq 0,70)$, nilai rata-rata pretest kelas kontrol 52,57 dan nilai rata-rata posttest $66,48, \mathrm{n}$ gain 0,29 berkategori rendah $(0,30<\mathrm{g} \geq 0,70)$. diperoleh perbedaan yang signifikan, nilai $\mathrm{Z}_{\text {hitung }}>$ $\mathrm{Z}_{\alpha}$ yaitu 5,47>1,96, maka $\mathrm{H}_{0}$ ditolak dan $\mathrm{H}_{\mathrm{a}}$ diterima. Tanggapan peserta didik terhadap penerapan metode pembelajaran team quiz berkategori sangat baik, diperoleh hasil persentase rata-rata $81,67 \%$.

Kata Kunci:

team quiz, motivasi belajar, hasil belajar kognitif
\end{abstract}




\section{PENDAHULUAN}

Baik dan buruknya kualitas pendidikan berkaitan erat dengan kualitas peserta didik karena titik pusat dalam proses belajar mengajar di sekolah adalah peserta didik. Peserta didik diharapkan dapat memperoleh ilmu serta wawasan di sekolah yang nantinya diharapkan akan berguna dimasa mendatang. Cara untuk mengukur kemampuan, pengetahuan dan pemahaman peserta didik tentang suatu mata pelajaran di sekolah yaitu dengan melihat proses belajar peserta didik. Hasil belajar merupakan pencerminan pencapaian peserta didik setelah melakukan usaha dalam belajar. Pembelajaran Fiqih diarahkan untuk mengantarkan peserta didik dapat memahami pokok-pokok hukum Islam dan tata cara pelaksanaannya untuk diaplikasikan dalam kehidupan sehingga menjadi muslim yang selalu taat menjalankan syariat Islam secara kaffah (sempurna).

Berdasarkan pengamatan awal di MTs Atta'zhimyah didapat informasi bahwa hasil belajar kognitif peserta didik pada mata pelajaran Fiqih di MTs Atta'zhimiyah masih tergolong rendah, banyak peserta didik yang memperoleh nilai dibawah KKM (Kriteria Ketuntasan Minimal). Hal tersebut dapat dilihat dari data nilai ulangan harian peserta didik yang banyak dibawah KKM. Selain hasil belajar kognitif yang rendah motivasi peserta didik mengikuti pembelajaran Fiqih dapat dikatakan sangat kurang, terbukti dengan sikap mereka yang kurang perhatian, mengobrol ketika pendidik menerangkan, sikap yang acuh ketika pembelajaran. Hal ini diduga karena metode mengajar pendidik kurang aktif dan masih bersifat monoton hanya terpusat pada metode ceramah sehingga mengoptimalkan keaktifan dan kemampuan utama pendidik.

Motivasi belajar merupakan hal penting dalam pendidikan, rendahnya motivasi belajar peserta didik akan berpengaruh terhadap kualitas pendidikan. Salah satu penyebab rendahnya motivasi dan hasil belajar kognitif peserta didik ini diasumsikan karena pembelajaran yang diterapkan oleh pendidik didominasi oleh metode ceramah serta hanya sebatas buku teks, sehingga peserta didik kurang termotivasi dalam belajar dan kurang memaknai pembelajaran. Akibatnya peranan, minat, dan kebutuhan peserta didik masih kurang diperhatikan, sehingga peserta didik menjadi kurang aktif dan kurang memiliki kemauan untuk belajar. Berdasarkan persoalan tersebut perlu dirancang metode pembelajaran yang sesuai, karena dalam proses pembelajaran, model, metode, strategi serta penyediaan sarana dan prasarana sebagai media pendukung dalam pembelajaran yang dilakukan oleh pendidik seharusnya menjadi sesuatu yang benarbenar tepat dan bermakna, untuk memperoleh hasil yang maksimal dalam meningkatkan hasil belajar peserta didik. Metode pembelajaran yang tepat sangat berdampak pada motivasi dan hasil belajar peserta didik. Salah satu metode pembelajaran yang melibatkan interaksi antara pendidik dengan peserta didik serta peserta didik dengan peserta didik lainnya adalah metode pembelajaran team quiz. Metode pembelajaran team quiz merupakan salah satu metode pembelajaran yang mampu meningkatkan motivasi belajar peserta didik sehingga hasil belajarnyapun akan meningkat. 
Dari pemaparan diatas, dapat ditarik rumusan masalah yang diambil dalam penelitian ini berkaitan dengan hal tersebut yaitu, 1) Bagaimana penerapan metode pembelajaran team quiz pada mata pelajaran Fiqih materi makanan dan minuman halal dan haram di kelas VIII MTs Atta'zhimiyah kota Bandung? 2)Bagaimana perbedaan motivasi belajar antara peserta didik yang menggunakan metode pembelajaran team quiz dengan peserta didik yang menggunakan metode konvensional pada mata pelajaran Fiqih materi makanan dan minuman halal dan haram di kelas VIII MTs Atta'zhimiyah kota Bandung? 3) Bagaimana perbedaan hasil belajar kognitif antara peserta didik yang menggunakan metode pembelajaran team quiz dengan peserta didik yang menggunakan metode konvensional pada mata pelajaran Fiqih materi makanan dan minuman halal dan haram di kelas VIII MTs Atta'zhimiyah kota Bandung? 4) Bagaimana tanggapan peserta didik terhadap penerapan metode pembelajaran team quiz pada mata pelajaran Fiqih materi makanan dan minuman halal dan haram di kelas VIII MTs Atta'zhimiyah kota Bandung?

Berkenaan dengan latar belakang dan rumusan masalah tersebut, penulis tertarik untuk mengkaji lebih mendalam mengenai penerapan metode pembelajaran team quiz dalam mengatasi problematika pembelajaran Fiqih, yang kemudian dirumuskan ke dalam sebuah judul "Penerapan Metode Pembelajaran Team Quiz dalam Meningkatkan Motivasi dan Hasil Belajar Kognitif Peserta Didik Pada Mata Pelajaran Fiqih Materi Makanan Dan Minuman Halal Dan Haram" (Penelitian Quasi Eksperiemn di MTs Atta’zhimiyah Kota Bandung Kelas VIII Tahun Pelajaran 2017-2018).

\section{KAJIAN PUSTAKA}

\section{Penerapan Metode Pembelajaran Team Quiz}

Penerapan adalah hal, cara atau hasil (Zain, 1996, p. 1487). Penerapan merupakan suatu perbuatan mempraktekkan suatu teori, metode, dan hal lain untuk mencapai tujuan tertentu dan untuk suatu kepentingan yang diinginkan oleh suatu kelompok atau golongan yang telah terencana. Berdasarkan pengertian tersebut dapat disimpulkan bahwa penerapan merupakan sebuah tindakan yang dilakukan baik secara individu maupun kelompok dengan maksud untuk mencapai tujuan yang telah dirumuskan. Sebagaimana yang telah dijelaskan sebelumnya bahwa metode adalah suatu cara yang dipergunakan untuk mencapai tujuan yang ditetapkan (Zain S. B., 2011, p. 46). Team quiz merupakan metode pembelajaran yang dikembangkan oleh Melvin L. Silberman sebagai pembelajaran aktif, team quiz adalah metode untuk meningkatkan kemampuan tanya jawab peserta didik terhadap apa yang mereka pelajari melalui cara yang menyenangkan dan tidak menakutkan (L.Silberman, 2013, p. 175). Pembelajaran aktif secara sederhana dapat didefinisikan sebagai metode pengajaran yang melibatkan siswa secara aktif dalam proses pembelajaran. Pembelajaran aktif mengkondisikan agar siswa selalu melakukan pengalaman belajar yang dapat dilakukaknnya selama pembelajaran (Hariyanto, 2012, p. 12). 
Metode team quiz adalah suatu kegiatan tanya jawab antar kelompok. Dalam kegiatan pembelajaran ini akan terjadi proses belajar yang tidak membosankan karena adanya komunikasi dan diskusi dari satu kelompok ke kelompok lain (Rahaju, 2014, p. 203). Mengajukan pertanyaan berarti menunjukkan pola pikir yang dimiliki oleh seseorang, sehingga bertanya dapat juga mendorong kemampuan siswa untuk berpikir (Yamin, 2007, p. 89). Bertanya merupakan suatu bentuk siswa untuk dapat mengetahui makna dari suatu hal ataupun suatu masalah sehingga dapat dicari solusi yang tepat dan dapat membangkitkan semangat dan pola pikir kritis. Metode team quiz merupakan kegiatan pembelajaran dengan berkelompok, masing-masing kelompok bertanggung jawab atas kelompoknya, mereka berdikusi, membuat pertanyaan serta menjawab pertanyaan antar kelompok, berkompetisi dengan cara yang menyenangkan. Berdasarkan uraian-uraian tersebut dapat ditegaskan bahwa penerapan metode pembelajaran team quiz merupakan pelaksanaan suatu cara penyampaian materi pembelajaran berbentuk kuis secara tim, peserta didik berkompetisi secara positif dengan metode ini diharapkan dapat menarik perhatian peserta didik dan dapat membangkitkan motivasi belajar peserta didik.

Adapun prosedur dalam pelaksanaan metode pembelajaran team quiz (L.Silberman, 2013, p. 158) adalah sebagai berikut:

a. Pilih topik atau pokok bahasan yang dapat dipresentasikan dalam tiga atau lebih bagian.

b. Kelompokkan peserta didik sesuai dengan jumlah pembagian topik.

c. Jelaskan kepada peserta didik bentuk sesi atau teknis pembelajaran. Selanjutnya persilahkan peserta didik mempelajari materi dalam beberapa menit dan mulai presentasi, batasi presentasi dalam 10 menit atau kurang.

d. Minta tim A untuk mempersiapkan kuis yang berjawaban singkat. Kuis ini tidak memakan waktu lebih dari 5 menit untuk persiapan, di lain pihak tim lain memanfaatkan waktu untuk meninjau ulang catatan mereka.

e. Tim A menguji anggota tim B. Jika tim B tidak bisa menjawab maka kesempatan diberikan kepada tim $\mathrm{C}$ untuk menjawabnya.

f. Tim A selanjutnya menguji tim $\mathrm{C}$, jika tim $\mathrm{C}$ tidak mampu menjawab maka pertanyaan diajukan ke tim B.

g. Ketika kuis untuk tim A selesai, lanjutkan dengan bagian ke dua dari materi pelajaran. Lanjutkan tim B sebagai pemimpin kuis dengan teknis yang sama seperti tim A.

h. Setelah tim B selesai lanjutkan dengan materi ke tiga. Tim C bertindak sebagai pemimpin kuis.

Dalam metode pembelajaran team quiz peserta didik dibagi menjadi beberapa kelompok anggota kelompok bersama-sama mempelajari materi tersebut dengan saling memberi arahan, memberikan pertanyaan dan jawaban untuk memahami mata pelajaran tersebut, setelah selesai mempelajari materi lalu diadakan pertandingan akademis, 
dengan adanya pertandingan ini maka terciptalah kompetisi antar kelompok, peserta didik akan senantiasa berusaha belajar dengan motivasi yang tinggi agar mendapat nilai yang tinggi dalam pertandingan, peserta didik dapat menyimpulkan materi pembelajaran secara menyeluruh.Setiap metode pembelajaran terdapat kelebihan dan kelemahan masing-masing begitu pula dengan metode team quiz. Setiap metode pembelajaran akan berhasil di gunakan apabila sesuai dengan materi dan tujuan pembelajaran serta karateristik peserta didik.

\section{Motivasi Belajar}

Menurut M. Ngalim Purwanto motivasi yaitu suatu usaha yang disadari untuk menggerakkan, mengarahkan, dan menjaga tingkah laku seseorang agar ia terdorong untuk bertindak melakukan sesuatu sehingga mencapai hasil atau tujuan tertentu (Purwanto, 2000, p. 73). Menurut James O. Whittaker yang dikutip Wasty Soemanto motivasi adalah kondisi-kondisi atau keadaan yang mengaktifkan atau memberi dorongan kepada makhluk untuk bertingkah laku mencapai tujuan yang ditimbulkan oleh motivasi tersebut (Soemanto, 2006, p. 205). Motivasi adalah pendorong setiap potensi yang ada dalam diri seorang manusia, sehingga manusia dapat mengoptimalkan apa yang ada dalam dirinya.

Motivasi membuat seseorang untuk melakukan suatu perbuatan yang menjadi tujuannya serta memilih perbuatan yang sesuai dengan tujuannya, motivasi menjadikan seseorang senang dalam melakukan sesuatu. Sedangkan belajar seperti yang telah dikemukakan sebelumnya belajar adalah suatu proses perubahan dalam pribadi manusia, dan perubahan tersebut ditampakan dalam bentuk peningkatan kualitas dan kuantitas tingkah laku seperti peningkatan kecakapan, pengetahuan, sikap, kebiasaan, pemahaman, keterampilan, daya pikir dan kemampuan lainnya. Jadi motivasi belajar merupakan dorongan internal dan eksternal individu yang sedang belajar untuk mengadakan perubahan tingkah laku yang bersifat berkesinambungan dan fungsional, bersifat positif dan aktif, bertujuan atau terarah, serta mencakup seluruh aspek tingkah laku.

Fungsi motivasi dalam belajar dan pembelajaran antara lain dalam (a) menentukan hal-hal yang dapat dijadikan penguat belajar, (b) memperjelas tujuan belajar yang hendak dicapai, (c) menentukan ragam kendali terhadap rangsangan belajar, (d) menentukan ketekunan belajar (Uno, 2012, p. 27). Karena fungsi motivasi dalam belajar sangatlah penting maka pendidik harus memperhatikan berbagai hal yang berhubungan dengan motivasi belajar peserta didik. Adapun beberapa ciri-ciri untuk mengetahui motivasi dalam diri seseorang menurut Abin Syamsudin menjelaskan indikator motivasi belajar dapat diklasifikasikan sebagai berikut (Makmun, 2007, p. 40):

a. Durasi kegiatan artinya berapa lama penggunaan waktu untuk melakukan kegiatan 
b. Frekuensi kegiatan artinya seberapa sering kegiatan dilakukan dalam periode waktu tertentu

c. Presistensi artinya ketetapan dan kelekatan pada tujuan

d. Ketabahan, keuletan dan kemampuannya dalam menghadapi rintangan dan kesulitan untuk mencapai tujuan

e. Devosi, artinya pengabdian dan pengorbanan baik berupa uang, tenaga pikiran bahkan jiwa untuk mencapai tujuan

f. Tingkat aspirasi artinya maksud, rencana, cita-cita sasaran atau target dan idola yang hendak dicapai dengan kegiatan yang dilakukannya.

g. Tingkat kualifikasi prestasi atau produk yang dicapai dari kegiatan berapa banyak, memadai atau tidak

h. Arah sikap terhadap sasaran kegiatan suka atau tidak suka, positif atau negatif.

\section{Hasil Belajar Kognitif}

Hasil belajar adalah kemampuan-kemampuan yang dimiliki siswa setelah menerima pengalaman belajarnya (Sudjana, 2004, p. 22). Hasil belajar yaitu pencapaian bentuk perubahan perilaku yang cenderung menetap dari ranah kognitif, afektif dan psikomotoris dari proses belajar yang dilakukan dalm waktu tertentu (Haris, 2012, p. 14). Pada umumnya hasil belajar akan memberikan pengaruh dalam dua bentuk: 1) peserta didik akan mempunyai persfektif terhadap kekuatan dan kelemahannya atas perilaku yang diinginkan; 2) mereka mendapatkan bahwa perilaku yang diinginkan itu telah meningkat baik setahap atau dua tahap sehingga tmbul lagi kesenjanan antara penampilan perilaku yang sekarang dengan perilaku yang diinginkan (Mulyasa, 2013, p. 208). Dalam penelitian ini lebih ditekankan untuk melihat hasil belajar pada ranah kognitif. Hal ini didasarkan pada waktu pemberian tes hasil belajar yang singkat. Kognitif (cognitive) adalah berasal dari kata cognition yang yang berarti mengetahui (Syah, 2012, p. 65).

Hasil belajar kognitif digunakan sebagai tolak ukur untuk mengetahui sejauhmana peserta didik menguasai bahan ajar yang telah diajakan oleh pendidik. A. De Block dalam W.S Winkel menyatakan bahwa ciri khas belajar kognitif terletak dalam belajar memeroleh dan menggunakan bentuk-bentuk representasi yang mewakili semua obyek yang dihadapi, entah obyek itu orang, benda atau peristiwa. Obyek-obyek itu direpresentasikan dalam diri seseorang melalui tanggapan, gagasan, atau lambing, yang semuanya merupakan suatu yan bersifat mental (Winkel, 2009, p. 115).

Hasil belajar kognitif adalah hasil usaha, bekerja atau belajar yang menunjukkan ukuran kecakapan yang telah dicapai melalui pengukuran dan penilaian terhadap penguasaan yang terdiri dari aspek mengingat, memahami, menerapkan, menganalisis, menilai, dan mencipta, yang diperoleh peserta didik melalui proses belajar yang dinyatakan dalam simbol, angka, huruf atau kode. Bagi pendidik hasil belajar kognitif 
berfungsi sebagai alat ukur dalam menentukan kesuksesan dalam mengajar dan menilai kelemahan dari sebuah pendekatan, strategi, model, metode, teknik dan media yang digunakan pada suatu pembelajaran. bagi peserta didik hasil belajar berfungsi untuk mengukur kemampuan dalam suatu pembelajaran.

Ranah kognitif merupakan bagian yang paling banyak dinilai oleh guru karena berkaitan dengan kemampuan para peserta didik dalam menguasai isi bahan pengajaran. Pengklasifikasian ranah kognitif oleh Bloom (1956) terbagi menjadi enam tingkatan yaitu, 1) pengetahuan, 2) pemahaman, 3) aplikasi, 4) analisis 5) sintesis, 6) evaluasi. Anderson dan Krathwohl merevisi keenam aspek pada ranah kognitif yang telah diklasifikasikan oleh Bloom tersebut menjadi. 1) Meningat, 2) Memahami, 3) mengaplikasikan, 4) menganalisis, 5) mengevaluasi, 6) Mencipta (Krathwohl, 2017, p. 43).

\section{a. Remembering (Mengingat)}

Proses mengingat adalah mengambil pengetahuan yang dibutuhan dari memori jangka panjang. Pengetahuan yang dibutuhkan ini berupa pengetahuan faktual, konseptuan, prosedural atau metakognitif, atau kombinasi dari beberapa pengetahuan ini (Krathwohl, 2017, p. 99). Pada proses ini kategori proses kognitifnya meliputi mengenali atau mengidentifikasi dan mengingat kembali. Proses mengenali yaitu mengambil pengetahuan dalam memori jangka panjang untuk membandingkannya dengan informasi baru yang diterima, selanjutnya mengingat kembali yaitu mengambil pengetahuan yang relevan dalam memori jangka panjang. Contoh kata kerja yang digunakan yaitu menyebutkan, menunjukan, mengenal, mengingat kembali, mendefinisikan, memilih, menyatakan, mengidentifikasi serta menetapkan (Daryanto, 2008, pp. 103-104).

\section{b. Understanding (Memahami)}

Aspek memahami meliputi kemampuan mengkontruksi makna dari materi pembelajaran dari berbagai fungsi atau pesan yang berbeda, seperti kegiatan menafsirkan, mencontohkan, mengklasifikasikan, merangkum, menduga, membandingkan, menjelaskan serta menyimpulkan. Pada tingkatan ini selain hafal peserta didik juga haru memahami makna yang terkandung. Contoh kata kerja yang digunakan yaitu menerjemahkan, mengubah, mengilustrasikan, menyajikan, menggolongkan, mengutip, mengubah, menyamaratakan, memberi contoh-contoh, menginterpretasikan, mengekstrapolasi, mengemukakan kembali dengan kata-kata sendiri, menyimpulkan serta memahami (Daryanto, 2008, pp. 106-108).

\section{c. Applying (Menerapkan)}

Menerapkan merupakan kemampuan peserta didik untuk melakukan sesuatu atau konsep dalam keadaan tertentu dan mengaplikasikan konsep dalam situasi tertentu (Krathwohl, 2017, p. 43). Pada proses ini kategori proses kognitifnya meliputi melaksanakan dan mengimplementasikan. Melaksanakan yaitu menerapkan suatu prosedur pada tugas yang familiar kemudian mengimplementasikan merupakan kegiatan 
menerapkan suatu prosedur pada suatu tugas yang tidak familiar.kata kerja yang digunakan yaitu memperaktikkan, menggunakan, mengembangkan, mengorganisasi, mengubah, menghitung, menentukian, memecahkan masalah, membangun, mengontrol, menentukan, menetapkan, melakasanakan, menerapkan, mempertunjukkan, serta memanfaatkan (Daryanto, 2008, p. 110).

d. Analyzing (Menganalisis)

Aspek menganalisis merupakan kemampuan menentukan bagaimana bagianbagian penyusunannya dan menentukan hubungan-hubungan antar bagian itu dan hubungan hubungan antara bagian-bagian tersebut dan keseluruhan struktur tujuan, termasuk kegiatan membedakan, mengorganisasikan, dan menghubungkan antar komponen.

e. Evaluating (Menilai)

Aspek menilai yaitu mengambil keputusan yang berkaitan dengan kemampuan membuat penilaian berdasarkan kriteria dan standar yang dapat berupa kritikan, rekomendasi, dan laporan.

\section{f. Creating (Menciptakan)}

Aspek menciptakan merupakan kemampuan untuk memadukan bagian-bagian untuk membentuk suatu yang baru dan koheren atau membuat suatu produk yang orisinal. Seperti merumuskan, merencanakan dan memproduksi.

Faktor-faktor yang mempengaruhi belajar siswa dapat dibedakan menjadi tiga macam, yakni: 1) faktor internal (faktor dari dalam siswa), yakni keadaan/kondisi jasmani dan rohani siswa. 2) Faktor eksternal (faktor dari luar siswa), yakni kondisi lingkungan di sekitar siswa. 3) Faktor pendekatan belajar, yakni jenis upaya belajar siswa yang meliputi strategi dan metode yang digunakan siswa untuk melakukan kegiatan mempelajari materi-materi pelajaran (Syah, 2012, p. 129).

\section{Pembelajaran Fiqih di Madrasah Tsanawiyah Materi Makanan Minuman Halal dan Haram}

Menurut Imam Ghazali mendefinisikan fiqih itu mengetahui dan memahami akan tetapi dalam tradisi ulama, fiqih diartikan dalam suatu syara' tertentu bagi perbatan mukallaf seperti wajib, haram, sunnah, mubah, makhruh, sah, fasad, batal dan sejenisnya (Dzajuli, 2005, p. 15). Ruang lingkup pembelajaran fiqih di Madrasah Tsanawiyah sebagaimana terdapat dalam KMA no 165 tahun 2014 meliputi:

a) Aspek fikih ibadah meliputi: ketentuan dan tatacara taharah, salat fardu, salat sunnah, dan salat dalam keadaan darurat, sujud, azan dan iqamah, berzikir dan berdoa setelah salat, puasa, zakat, haji dan umrah, kurban dan akikah, makanan, perawatan jenazah, dan ziarah kubur.

b) Aspek fikih muamalah meliputi: ketentuan dan hukum jual beli, qirad, riba, pinjam- meminjam, utang piutang, gadai, dan agunan serta upah. 
Dilihat dari segi pengamalan ajaran Islam yang jelas pengajaran fiqih ini adalah pengajaran yang bersifat amaliah, harus mengandung unsur teori dan praktek. Bidang studi Fiqih itu bertujuan untuk membekali peserta didik agar dapat mengetahui dan memahami pokok-pokok hukum Islam secara terperinci dan menyeluruh. Pengetahuan dan pemahaman tersebut menjadi pedoman hidup dalam kehidupan pribadi dan sosial. Materi makanan dan minuman halal dan haram terdapat dalam pembelajaran fiqih di Madrasah Tsanawiyah kelas VIII dan jika dilihat dalam ruang lingkup mata pelajaran fikih materi tersebut merupakan aspek fiqih ibadah.

a. Makanan Halal

Halal artinya boleh, jadi makanan yang halal ialah makanan yang dibolehkan untuk dimakan menurut ketentuan syari'at Islam. segala sesuatu baik berupa tumbuhan, buah-buahan ataupun binatang pada dasarnya adalah hahal dimakan, kecuali apabila ada nash Al-Quran atau Al-Hadits yang mengharamkannya. Secara garis besar makanan halal dikelompokkan menjadi tiga,yaitu :

1. Halal berdasarkan zat-nya. Artinya barang tersebut memang tidak dilarang dalam hukum syara'. Contohnya:, a) berasal dari tumbuhan berupa bijibijian, buah-buahan, dan sayur-mayur. Seperti jagung, padi, kacang, jeruk,dan sebagainya; b) binatang darat. Semua binatang darat dihalalkan; c) binatang air. d) bangkai ikan dan belalang. e) semua makanan yang tidak mendatangkan mudharat; f) semua makanan yang baik, yakni tidak kotor dan tidak menjijikan.

2. Halal cara mendapatkannya. Bukan hasil mencuri, korupsi, menipu dan lainlain.

3. Halal cara memprosesnya/mengolahnya.

\section{b. Makanan Haram}

Haram artinya dilarang, jadi makanan yang haram adalah makanan yang dilarang oleh syara' untuk dimakan. Setiap makanan yang dilarang oleh syara' pasti ada bahayanya dan meninggalkan yang dilarang syara' pasti ada faidahnya (Ibrahim, p. 92). Makanan yang diharamkan adalah :

1. Semua makanan yang diharamkan oleh Allah dan Rasul

2. Semua jenis makanan yang dapat mendatangkan mudharat terhadap jiwa, raga, akal, moral dan aqidah.

3. Bagian yang dipotong dari binatang yang masih hidup.

4. Makanan yang didapat dengan cara yang tidak halal seperti makanan hasil curian, rampasan, korupsi, riba dan cara-cara lain yang dilarang agama.

5. Binatang yang diharamkan antara lain: a) Binatang yang mampu tahan lama hidup di darat dan di air,yaitu katak,buaya,kura-kura dn sebagainya; b) himar atau keledai jinak; c) semua binatang yang bertaring kuat; d) semua binatang yang mempunyai kuku tajam; e) binatang yang diperintah untuk dibunuh seperti tikus, kalajengking, burung gaak, cicak/toke, ular; f) bintang yang 
dilarang untuk dibunuh seperti semut, lebah, hud-hud dan shurad; g) binatang yang kotor atau menjijikan, seperti kutu, ulat, cacing, lintah, lalat, lebah, laba-laba, nyamuk, kumbang, dan sejeninsnya.

c. Minuman Halal

Ciri-ciri minuman halal yaitu semua minuman yang baik, tidak kotor dan tidak menjijikan, semua minuman yang tidak diharamkan oleh Allah dan Rasul-Nya, semua minuman yang tidak memberi mudharat, tidak membahayakan kesehatan jasmani dan tidak merusak akal, moral, dan aqidah. Minuman yang halal pada dasarnya dapat dibagi menjadi 4 bagian (Ibrahim, p. 91):

1. Semua jenis aiar atau cairan yang tidak membahayakan bagi kehidupan manusia, baik membahayakan dari segi jasmani, akal, jiwa, maupun aqidah.

2. Air atau cairan yang tidak memabukkan walaupun sebelumnya pernah memabukkan seperti arak yang berubah menjadi cuka.

3. Air atau cairan itu bukan berupa benda najis atau benda suci yang terkena najis.

4. Air atau cairan yang suci itu didapatkan dengan cara-cara yang halal yang tidak bertentangan dengan ajaran agama Islam.

d. Minuman yang Haram

Minuman haram adalah minuman yang diharamkan untuk dikonumsi oleh manusia menurut syari' at Islam. Minuman yang haram di antaranya mengandung unsur memabukkan yang disebut Khamr.

1. Semua minuman yang memabukkan atau apabila diminum menimbulkan mudharat dan merusak badan, akal, jiwa, moral dan aqidah seperti arak, khamar, dan sejenisnya. Minuman dari benda najis atau benda yang terkena najis.

2. Minuman yang didapatkan dengan cara-cara yang tidak halan atau yang bertentangan dengan ajaran Islam.

e. Hikmah Dihalalkan Makanan

Dari beberapa makanan dan minuman yang diharamkan oleh Allah ada isyarat hikmah yang terkandung di dalamnya. Hikmah yang terkandung antara lain :

1. Minuman yang memabukkan diharamkan karena di dalamnya mengandung zat etanol atau metanol yang bersifat racun, sehingga membahayakan kesehatan manusia terutama merusak jaringan otak dan sarat.

2. Diharamkannya babi karena di dalamnya mengandung cacing pita yang dapat tumbuh dalam lambung mabusia dan akan merusak alat pencernakan.

3. Diharamkan bangkai karena bangkai tersebut kemungkinan mengandung mikroba-mikroba atau baksil yang akan meracuni dan merusak tubuh manusia 
4. Makanan yang menjijikkan atau kotor diharamkan, karena makanan tersebut dapat mengotori tubuh kita dan akan menjadi racun dalam tubuh yang akan mengganggu pertumbuhan jasmani dan rohani.

5. Dapat disimpulkan bahwa diharamkannya makanan dan minuman merupakan salah satu bentuk kasih sayang Allah kepada manusia. Dengan menghayati ketentuan Allah tersebut akan tumbuh kesadaran bahwa betaapa kasih sayang Allah terhadap hambaNya sangatlah besar.

f. Dampak Makanan dan Minuman Haram

Memakan makanan dan minuman yang haram dilarang oleh Allah dan rasulNya, sebab akan berakibat bagi yang mengkonsumsinya. Beberapa akibat yang ditimbulkan antara lain:

1. Akan mendapatkan murka dan azab dari allah baik didunia maupun diakhirat.

2. Tidak ada keberkahan dalam dirinya.

3. Akan membentuk sifat-sifat syaithoniyah seperti suka marah, berbohong, dan berkhianat.

4. Susah menerima ilmu kebenaran.

5. Badan tidak sehat dan mudah terkena berbagai macam penyakit.

\section{METODOLOGI PENELITIAN}

Pendekatan yang digunakan dalam penelitian ini pendekatan kuantitatif. pengumpulan data menggunakan instrument penelitian, analisis data bersifat kuantitatif atau statistik dengan tujuan untuk menguji hipotesis yang telah dirumuskan. Metode penelitian ini adalah metode eksperimen, Eksperimen merupakan metode penelitian dengan ciri khas adanya perlakuan. Penelitian yang digunakan dalam penelitian ini yaitu quasi experiment. Tujuannya adalah untuk memprediksi keadaan yang dapat dicapai melalui eksperimen yang sebenarnya dan tidak ada manipulasi terhadap seluruh variabel yang relevan (Arifin, 2011, p. 74). Desain penelitian yang digunakan dalam penelitian ini ialah non equivalent control group design. Sebelum diberi treatment, baik kelompok eksperimen dan kelompok kontrol diberi tes yaitu pretest, dengan maksud untuk mengetahui keadaan kelompok sebelum treatment. Kemudian setelah diberikan treatment, Kelompok eksperimen dan kelompok kontrol diberikan tes yaitu posttest, untuk mengetahui keadaan kelompok setelah treatment. Rancangan penelitian tersebut adalah sebagai berikut (Sugiyono, 2010, p. 76). 
Tabel 1

Desain Penelitian

\begin{tabular}{|l|l|l|l|}
\hline Kelas Eksperimen & $\mathrm{O}_{1}$ & $\mathrm{X}$ & $\mathrm{O}_{2}$ \\
\hline Kelas Kontrol & $\mathrm{O}_{1}$ & & $\mathrm{O}_{2}$ \\
\hline
\end{tabular}

Keterangan:

$\mathrm{O}_{1} \quad$ : Pretest

$\mathrm{O}_{2} \quad$ : Posttest

$\mathrm{X} \quad$ : Treatment (Penggunaan metode pembelajaran team quiz)

Jenis data yang dihasilkan dari penelitian ini berupa fakta dan angka. Sehingga dalam penelitian ini peneliti menggunakan jenis data kualitatif dan kuantitatif. Kualitatif adalah data-data dari literatur atau dokumen-dokumen yang menunjang penelitian ini dan kuantitatif adalah tentang penerapan metode pembelajaran team quiz dalam meningkatkan motivasi dan hasil belajar peserta didik pada mata pelajaran fiqih yang berupa angka-angka atau data kualitatif yang diangkakan (scoring). Sumber data dalam penelitian ini adalah subjek darimana data diperoleh (Arikunto, 2015, p. 125). Sumber data dalam penelitian ini terdiri dari data primer dan data sekunder. Data primer dalam penelitian ini diperoleh dari responden-responden yang terdiri dari siswa MTs Atta'zhimiyah Bandung melalui angket dan tes. Sedangkan data sekunder berasal dari data-data lain yang berkaitan dengan masalah penelitian. Data sekunder ini diperoleh dari buku-buku, teori, beberapa dokumen dan arsip-arsip yang menunjang penelitian.

Lokasi penelitian dilakukan di MTs Atta'zhimiyah, populasi dalam penelitian ini adalah peserta didik kelas VIII MTs Atta'zhimiyah yang terdaftar pada tahun ajaran 2017/2018 dengan jumlah 123 peserta didik. Teknik pengambilan sampel pada populasi dalam penelitian ini menggunakan teknik nonprobability sampling, yaitu teknik pengambilan sampel yang tidak memberi peluang sama bagi setiap unsur atau anggota populasi untuk dipilih menjadi sampel (Sugiyono, 2010, p. 122). Jenis sampling purposive, peneliti mengambil sampel kelas VIII-B dengan jumlah peserta didik 30 sebagai kelas eksperimen dan kelas VIII-C dengan jumlah peserta didik 30 sebagai kelas kontrol, sehingga jumlah sampel dalam penelitian ini sebanyak 60 dari 123 peserta didik. pengambilan sampel tersebut berdasarkan nilai rata-rata fiqih yang diperoleh pada setiap kelas, kelas $\mathrm{B}$ dan kelas $\mathrm{C}$ memperoleh nilai rata-rata yang rendah dibanding dengan kelas lainnya. Untuk mengetahui dan memperoleh data yang dibutuhkan, maka penulis menggunakan beberapa teknik tes dan non tes diataranya, 1) observasi, 2) wawancara, 3) angket, 4) tes, 5) Studi Pustaka, 6) Dokumentasi. Teknik analisis data yang digunakan dalam penelitian ini adalah analisis statistik deskriptif pada instrumen tes dan angket.

\section{HASIL TEMUAN DAN PEMBAHASAN}

\section{Pelaksanaan Pembelajaran Fiqih dengan Menggunakan Metode Team Quiz}


Pelaksanaan pembelajaran Fiqih di kelas eksperimen yaitu kelas VIII-B dimulai tanggal 5 Februari 2018. Kelas VIII-B terdiri dari 30 Peserta didik, dengan rincian lakilaki berjumlah 16 peserta didik dan perempuan berjumlah 14 peserta didik. Pelaksanaan pembelajaran di kelas eksperimen pendidik menggunakan metode pembelajaran team quiz. Kegiatan pembelajaran berlangsung selama 6 kali pertemuan. Pertemuan pertama peserta didik terlebih dahulu diberikan pretest atau tes awal dengan tujuan untuk mengetahui keadaan awal peserta didik sebelum mengikuti pembelajaran Fiqih dengan menggunakan metode team quiz. Pertemuan kedua sampai pertemuan kelima dilaksanakan proses pembelajaran Fiqih dengan menggunakan metode team quiz sesuai dengan RPP yang telah dirancang sebelumnya oleh pendidik. Selanjutnya untuk pertemuan keenam atau pertemuan terakhir peserta didik diberikan posttest atau tes akhir untuk mengetahui peningkatan hasil belajar konitif peserta didik, lembar angket motivasi belajar dan angket tanggapan peserta didik terhadap pembelajaran dengan metode team quiz.

Pelaksanaan pembelajaran di kelas kontrol di mulai tanggal 7 Februari 2018. Kelas kontrol yang digunakan dalam penelitian ini yaitu kelas VIII-C yang terdiri dari 30 peserta didik. Pelaksanaan pembelajaran di kelas kontrol menggunakan metode pembelajaran konvensional (ceramah). Kegiatan pembelajaran berlangsung selama 6 kali pertemuan. Pertemuan pertama peserta didik terlebih dahulu diberikan pretest untuk mengetahui keadaan awal peserta didik sebelum mengikuti pembelajaran Fiqih. Pertemuan kedua sampai pertemuan kelima dilaksanakan pembelajaran konvensiaonal sesuai dengan RPP yang telah dirancang sebelumnya. Selanjutnya dipertemuan keenam peserta didik diberikan posttest dan angket motivasi belajar. Posttest untuk mengukur hasil belajar kognitif peserta didik setelah mengikuti proses pembelajaran Fiqih dengan menggunakan metode pembelajaran konvensional. Angket motivasi belajar untuk mengukur motivasi belajar peserta didik pada mata pelajaran Fiqih.

\section{Perbedaan Motivasi Belajar}

Pernyataan dalam variabel $\mathrm{Y}_{1}$ merupakan hasil dari pengembangan 9 indikator yaitu: 1) durasi kegiatan, 2) frekuensi kegiatan, 3) presistensi pada tujuan kegiatan, 4) ketabahan, keuletan dan kemampuannya dalam menghadapi rintangan dan kesulitan, 5) devosi (pengabdian dan pengorbanan), 6) tingkat aspirasi, 7) tingkat kualifikasi dan 8) arah sikap terhadap sasaran. Setiap item pernyataan dihitung persentasenya dengan rumus (jumlah skor sikap yang diperoleh : jumlah skor tertinggi likert) x 100, untuk ratarata persentase skor positif sikap peserta didik yang diperoleh, diinterpresentasikan dengan keriteria berikut:

$\begin{array}{ll}0 \%-19,99 \% & \text { Sangat Rendah } \\ 20 \%-39,99 \% & \text { Rendah } \\ 40 \%-59,99 \% & \text { Sedang } \\ 60 \%-79,99 \% & \text { Tinggi } \\ 80 \%-100 \% & \text { Sangat Tinggi }\end{array}$


Perbedaan skor rata-rata angket motivasi belajar (variabel $\mathrm{Y}_{1}$ ) peserta didik kelas eksperimen (kelas VIII-B) dan kelas kontrol (kelas VIII-C) ditunjukan dalam gambar 1.

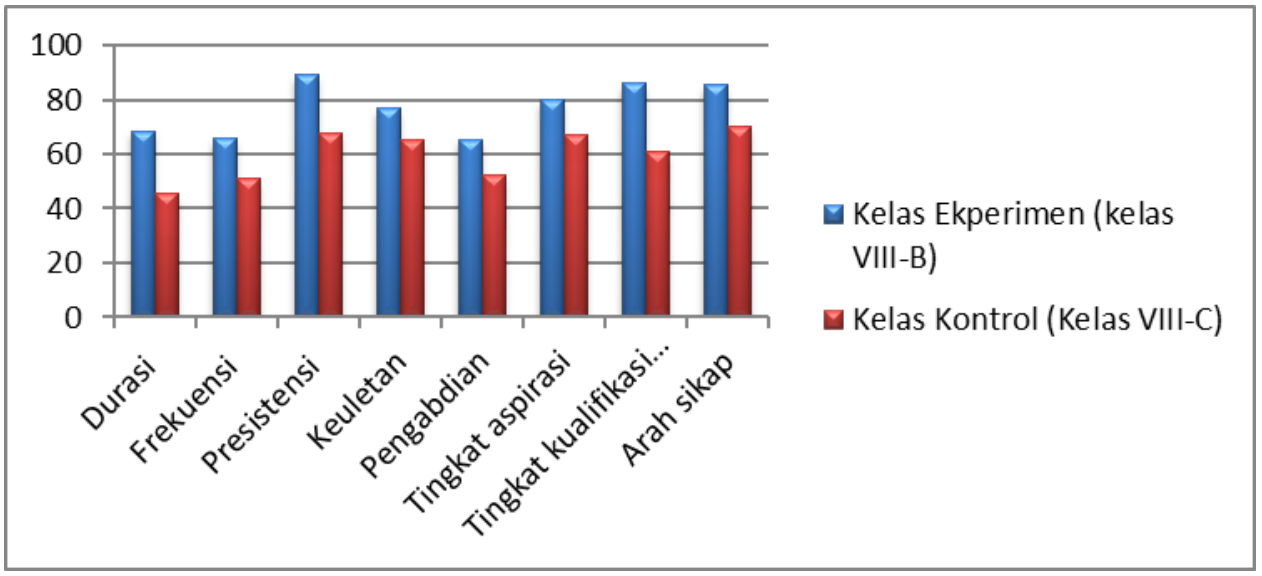

Gambar 1. Garafik Perbedaan Persentase Skor Rata-rata Motivasi Belajar

Dengan melihat hasil perhitungan, hasil pengujian normalitas pada kelas VIII-B sebagai kelas ekperimen diperoleh $\chi^{2}$ hitung $=22,>\chi_{\text {tabel }}^{2}=7,81$ pada taraf signifikan $5 \%$. Maka data angket motivasi belajar kelas ekperimen berdistribusi tidak normal. Sedangkan pada kelas VIII-C sebagai kelas kontrol diperoleh $\chi_{\text {hitung }}^{2}=3,63<\chi_{\text {tabel }}^{2}=$ 7,81 pada taraf signifikan 5\%. Maka data angket motivasi belajar kelas kontrol berdistribusi normal. Hasil perhitungan uji homogenitas diperoleh $F_{\text {hitung }}=3,93$ dan dari tabel distribusi $\mathrm{F}$ diperoleh nilai $\mathrm{F}_{\text {tabel }}=1,86$, maka Fhitung $>$ Ftabel $(3,93>1,86)$ untuk hasil angket variabel $\mathrm{Y}_{1}$ motivasi belajar antara peserta didik kelas eksperimen dan peserta didik kelas kontrol, dapat disimpulkan bahwa data tersebut memiliki varians yang tidak homogen. Hasil pengujian hipotesis Uji Mann Whitney $U$ diperoleh $\mathrm{Z}_{\text {hitung }}=6,65$ dan $\mathrm{Z}_{\alpha}=1,96$ pada pengujian dua sisi, karena diperoleh $\mathrm{Z}_{\text {hitung }}>$ $\mathrm{Z}_{\alpha}$ yaitu 6,65 > 1,96, maka $\mathrm{H}_{0}$ ditolak dan $\mathrm{H}_{\mathrm{a}}$ diterima, artinya terdapat perbedaan motivasi belajar peserta didik yang menggunakan metode pembelajaran team quiz dengan peserta didik yang menggunakan metode konvensional. Hal tersebut menunjukan bahwa motivasi belajar peerta didik yang menggunakan metode pembelajaran team quiz lebih tinggi dibandingkan dengan peserta didik yang menggunakan metode pembelajaran konvensional dalam pembelajaran Fiqih materi makanan minuman halal dan haram.

\section{Perbedaan Hasil Belajar Kognitif}

Untuk mengetahui perbedaan hasil belajar kognitif peserta didik sebelum dan sesudah mengikuti pembelajaran Fiqih dengan metode pembelajaran team quiz materi makanan dan minuman halal dan haram serta perbedaan hasil belajar antara peserta didik yang menggunakan metode pembelajaran team quiz dengan peserta didik yang mengunakan metode pembelajaran konvensional di kelas VIII MTs Atta'zhimiyah kota Bandung, diajukan 25 pertanyaan pretest dan 25 pertanyaan posttest dalam bentuk tes 
pilihan ganda (PG) yang disebarkan kepada 60 peserta didik. pertanyaan pada variabel $\mathrm{Y}_{2}$ merupakan hasil dari pengembangan dari 4 indikator yaitu: 1) mengingat, 2) memahami, 3) mengaplikasikan, 4) menganalisis dan 5) mengevaluasi 6) mencipta. Peningkatan hasil belajar kognitif (variabel $\mathrm{Y}_{2}$ ) ialah data hasil pretest dan posttest masing-masing kelas data tersebut kemudian dianalisis untuk melihat skor hasil tes. Berdasarkan hasil dari perhitungan uji n-gain kelas VIII-B sebagai kelas eksperimen dan kelas VIII-C sebagai kelas kontrol diperoleh nilai rata-rata pretest, posttest dan n-gain seperti ditunjukan dalam tabel 3.

Tabel 3.

Rata-rata Pretest, Posttets, dan N-Gain Variabel $\mathrm{Y}_{2}$

\begin{tabular}{|l|l|l|l|l|}
\hline Kelas & Pretest & Posttest & N-Gain & Interpretasi N-Gain \\
\hline Eksperimen (VIII-B) & 51,62 & 83,62 & 0,67 & Sedang \\
\hline Kontrol (VIII-C) & 52,57 & 66,48 & 0,29 & Rendah \\
\hline
\end{tabular}

Berdasarkan data yang diperoleh dari hasil belajar kognitif peserta didik (variabel $\mathrm{Y}_{2}$ ), diperoleh nilai rata-rata pretest hasil belajar kognitif kelas eksperimen sebelum dilaksanakan pembelajaran dengan menggunakan metode team quiz sebesar 51,62, dan nilai rata-rata posttest sebesar 83,62, nilai rata-rata n-gain pada kelas eksperimen menunjukan peningkatan nilai kognitif peserta didik sebesar 0,67 angka tersebur termasuk pada kategori sedang $(0,30<\mathrm{g} \geq 0,70)$. Sedangkan nilai rata-rata pretest hasil belajar kognitif kelas kontrol sebelum dilaksanakan pembelajaran sebesar 52,57 , dan nilai rata-rata posttest sebesar 66,48 , nilai rata-rata n-gain pada kelas kontrol menunjukan peningkatan nilai kognitif peserta didik sebesar 0,29 angka tersebur termasuk pada kategori rendah $(0,30<\mathrm{g} \geq 0,70)$.

Hasil pengujian normalitas data pretest pada kelas VIII-B sebagai kelas eksperimen diperoleh $\chi^{2}$ hitung $=30,4$ dan hasil $\chi_{\text {tabel }}^{2}=7,81$ pada taraf signifikansi $5 \%$. Ternyata hasil perhitungan diperoleh bahwa $\left(\chi^{2}\right.$ hitung $)=30,4>\left(\chi_{\text {tabel }}^{2}\right)=7,81$. Sedangkan hasil pengujian normalitas kelas VIII-C sebagai kelas kontrol diperoleh $\chi^{2}$ hitung $=42,82$ dan hasil $\chi_{\text {tabel }}^{2}=7,81$ pada taraf signifikansi $5 \%$. Ternyata hasil perhitungan diperoleh bahwa $\left(\chi^{2}\right.$ hitung $)=42,82>\left(\chi_{\text {tabel }}^{2}\right)=7,81$. Dapat disimpulkan bahwa data pretest kelas eksperimen dan kelas kontrol (variabel $\mathrm{Y}_{2}$ ) hasil belajar kognitif peserta didik dalam mengerjakan soal mata pelajaran Fiqih materi makanan dan minuman halal dan haram berdistribusi tidak normal. Hasil pengujian normalitas data posttest pada kelas VIII-B sebagai kelas eksperime diperoleh diperoleh $\chi^{2}$ hitung $=24,02$ dan hasil $\chi_{\text {tabel }}^{2}=7,81$ pada taraf signifikansi 5\%. Ternyata hasil perhitungan diperoleh bahwa $\left(\chi_{\text {hitung }}^{2}\right)=24,02>\left(\chi_{\text {tabel }}^{2}\right)=7,81$. Dapat disimpulkan bahwa data posttest kelas eksperimen dan kelas kontrol (variabel $\mathrm{Y}_{2}$ ) hasil belajar kognitif peserta didik dalam mengerjakan soal mata pelajaran Fiqih materi makanan dan minuman halal dan haram berdistribusi tidak normal. Sedangkan hasil pengujian normalitas kelas VIII-C sebagai 
kelas kontrol diperoleh $\chi^{2}$ hitung $=5,61$ dan hasil $\chi_{\text {tabel }}^{2}=7,81$ pada taraf signifikansi $5 \%$. Ternyata hasil perhitungan diperoleh bahwa $\left(\chi^{2}\right.$ hitung $)=5,61<\left(\chi_{\text {tabel }}^{2}\right)=7,81$. Dapat disimpulkan bahwa data posttest kelas kontrol variabel $\mathrm{Y}_{2}$ hasil belajar kognitif peserta didik dalam mengerjakan soal mata pelajaran Fiqih materi makanan dan minuman halal dan haram berdistribusi normal.

Uji homogenitas pretest (variabel $\mathrm{Y}_{1}$ ) peserta didik kelas VIII-B sebagai kelas ekperimen dan kelas VIII-C sebagai kelas kontrol diperoleh nilai $F_{\text {hitung }}=1,28$ dan dari tabel distribusi $\mathrm{F}$ diperoleh nilai $\mathrm{F}_{\text {tabel }}=1,86$, maka Fhitung $<$ Ftabel $(1,28<1,86)$ untuk hasil pretest variabel $\mathrm{Y}_{2}$ hasil belajar kognitif antara peserta didik kelas eksperimen dan peserta didik kelas kontrol sebelum diberikan perlakuan, dapat disimpulkan bahwa data tersebut memiliki varians yang homogen. Uji homogenitas posttest (variabel $\mathrm{Y}_{1}$ ) peserta didik kelas VIII-B sebagai kelas ekperimen dan kelas VIII-C sebagai kela kontrol diperoleh nilai $\mathrm{F}_{\text {hitung }}=1,91$ dan dari tabel distribusi $\mathrm{F}$ diperoleh nilai $\mathrm{F}_{\text {tabel }}=1,86$, maka Fhitung $>$ Ftabel $(1,91>1,86)$ untuk hasil posttest variabel $\mathrm{Y}_{2}$ hasil belajar kognitif antara peserta didik kelas eksperimen dan peserta didik kelas kontrol setelah diberikan perlakuan, dapat disimpulkan bahwa data tersebut memiliki varians yang tidak homogen.

Hasil pengujian hipotesis Uji Mann Whitney $U$ hasil perhitungan diperoleh $\mathrm{Z}_{\text {hitung }}=5,47$ dan $\mathrm{Z}_{\mathrm{a}}=1,96$ pada pengujian dua sisi, maka $\mathrm{Z}_{\text {hitung }}>\mathrm{Z}_{\text {á yaitu 5,47 }}$ $>1,96$, maka $\mathrm{H}_{0}$ ditolak dan $\mathrm{H}_{\mathrm{a}}$ diterima, artinya terdapat perbedaan hasil belajar kognitif peserta didik yang menggunakan metode pembelajaran team quiz lebih tinggi dibandingkan dengan peserta didik yang menggunakan metode konvensional. Hal tersebut menunjukan bahwa hasil belajar kognitif peserta didik yang menggunakan metode pembelajaran team quiz lebih tinggi dibandingkan dengan peserta didik yang menggunakan metode pembelajaran konvensional dalam pembelajaran Fiqih materi makanan minuman halal dan haram.

\section{Tanggapan Peserta Didik Terhadap Penerapan Metode Pembelajaran Team Quiz}

Untuk mengetahui tanggapan peserta didik terhadap penerapan metode pembelajaran team quiz pada mata pelajaran Fiqih materi makanan dan minuman halal dan haram di kelas VIII MTs Atta'zhimiyah kota Bandung, diajukan 15 item pernyataan dengan menggunakan angket skala Likert dengan alternatif lima jawaban yang meliputi, selalu (SL), sering (SR), kadang-kadang (KK), jarang (J), dan tidak pernah (TP). Untuk pernyataan positif tiap option memiliki masing-masing skor yaitu option $\mathrm{Sl}=5, \mathrm{SR}=4$, $\mathrm{KK}=3, \mathrm{~J}=2$ dan $\mathrm{TP}=1$.

Pernyataan variabel X merupakan hasil pengembangan dari 9 indikator yaitu, 1) Menyampaikan materi secara garis besar; 2) Menjelaskan teknis pembelajaran; 3) Mengelompokan peserta didik secara heterogen; 4) Membagi topik atau pokok bahasan; 5) Diskusi tim; 6) Presentasi tim; 7) Mengatur jalannya quiz; 8) Memberi poin penilaian untuk setiap tim; 9) membuat kesimpulan bersama-sama. Hasil perhitungan 
persentase rata-rata skor dari 9 indikator tanggapan peserta didik terhadap metode pembelajaran team quiz (variabel $\mathrm{X}$ ) diperoleh persentase rata-rata $81,67 \%$ dan di interpretasikan ke dalam skala 100 termasuk kategori sangat baik, karena berada dalam interval $80 \%-100 \%$. Hal ini menunjukan tanggapan peserta didik terhadap metode pembelajaran team quiz dalam pembelajaran Fiqih materi makanan dan minuman halal dan haram, berkategori sangat baik. Berdasarkan hasil perhitungan uji normalitas variabel $\mathrm{X}$ diperoleh $\chi^{2}$ hitung $=79,8$ dan hasil $\chi_{\text {tabel }}^{2}=7,81$ pada taraf signifikansi $5 \%$. Ternyata hasil perhitungan diperoleh bahwa $\left(\chi_{\text {hitung }}^{2}\right)=79,8>\left(\chi_{\text {tabel }}^{2}\right)=7,81$. Dapat disimpulkan bahwa data variabel $\mathrm{X}$ berupa angket tanggapan peserta didik terhadap penerapan metode team quiz dalam pembelajaran Fiqih materi makanan dan minuman halal dan haram berdistribusi tidak normal.

Penelitian ini dilaksanakan di MTs Atta'zhimiyah Kota Bandung, Pelaksanaan penelitian dimulai pada tanggal 22 Januari 2018 sampai 14 Maret 2018. Berdasarkan analisis data awal, hasil perhitungan diperoleh nilai rata-rata pretest kelas VIII-B sebesar 51,62 dan diinterpretasikan ke dalam skala 100 termasuk kategori kurang karena berada dalam interval 50-59, nilai rata-rata pretest kelas VIII-C sebesar 52,57 dan diinterpretasikan kedalam skala 100 termasuk kategori kurang karena berada dalam interval 50-59. Hasil perhitungan uji normalitas untuk kelas VIII-B diperoleh $\chi^{2}$ hitung $=$ 30,4 dan hasil $\chi_{\text {tabel }}^{2}=7,81$ pada taraf signifikansi 5\%. Karena diperoleh $\chi^{2}$ hitung $=30,4$ $>\chi_{\text {tabel }}^{2}=7,81$ maka data pretest kelas eksperimen variabel $\mathrm{Y}_{2}$ berdistribusi tidak normal. Untuk kelas VIII-C diperoleh $\chi^{2}$ hitung $=42,82$ dan hasil $\chi_{\text {tabel }}^{2}=7,81$ pada taraf signifikansi 5\%. Karena diperoleh $\chi^{2}$ hitung $=42,82>\left(\chi_{\text {tabel }}^{2}\right)=7,81$. Dapat disimpulkan bahwa data nilai pretest kelas kontrol variabel $\mathrm{Y}_{2}$ berdistribusi tidak normal. Hasil perhitungan uji homogenitas pretest diperoleh $\mathrm{F}_{\text {hitung }}=1,28$ dan dari tabel distribusi $\mathrm{F}$ diperoleh nilai $\mathrm{F}_{\text {tabel }}=1,86$ pada taraf signifikansi 5\%, maka Fhitung < Ftabel $(1,28<$ 1,86) maka keadaan awal peserta didik kelas VIII-B dan peserta didik kelas VIII-C sebelum diberikan perlakuan adalah sama (homogen). Oleh karena itu kedua kelas tersebut layak dijadikan kelas eksperimen dan kelas kontrol.

Selanjutnya kedua kelas diberikan pembelajaran Fiqih materi makanan minuman halal dan haram dengan perlakuan yang berbeda. Kelas VIII-B diberi perlakuan dnegan menggunakan metode pembelajaran team quiz dan kelas VIII- diberi perlakuan dengan menggunakan metode pembelajaran konvensional. Menurut Syaiful Bahri Djamarah dan Aswan Zain metode adalah suatu cara yang dipergunakan untuk mencapai tujuan yang ditetapkan (Zain S. B., 2011, p. 46). Melalui metode pembelajaran, mata pelajaran dapat disampaikan secara efisien, efektif dan terukur dengan baik, sehingga dapat dilakukan perencanaan dan perkiraan dengan tepat (Nata, 2011, p. 176). Setelah kedua kelas melaksanakan pembelajaran Fiqih peneliti memberikan tes akhir (posttest) untuk mengetahui keadaan akhir peserta didik. Berdasarkan hasil posttest yang telah diberikan, diperoleh nilai rata-rata hasil belajar kognitif kelas VIII-B sebesar 83,62. Sedangkan perolehan nilai rata-rata hasil belajar kognitif kelas VIII-C sebesar 66,48. Hasil rata-rata 
nilai posttest kelas VIII-B lebih tinggi dibandingkan dengan nilai rata-rata kelas VIII-C. Hasil belajar kognitif digunakan sebagai tolak ukur untuk mengetahui sejauhmana peserta didik menguasai bahan ajar yang telah diajakan oleh pendidik. Secara garis besar, ragam alat evaluasi terdiri dari dua macam bentuk, yaitu: 1) bentuk objektif dan 2) bentuk subjektif (Syah, 2012, p. 144).

Hasil perhitungan uji homogenitas posttest diperoleh $\mathrm{F}_{\text {hitung }}=1,91$ dan dari tabel distribusi $\mathrm{F}$ diperoleh nilai $\mathrm{F}_{\text {tabel }}=1,86$, maka Fhitung $>$ Ftabel $(1,91>1,86)$ untuk hasil posttest variabel $\mathrm{Y}_{2}$ bahwa data tersebut memiliki varians yang tidak homogen, maka keadaan akhir peserta didik kelas VIII-B dan kelas VIII-C hasil belajar kognitif kedua kelas setelah diberi perlakuan tidak sama. Analisis akhir hasil belajar kognitif (variabel $\mathrm{Y}_{2}$ ) dilakukan uji signifikansi dengan menggunakan uji statistik non-parametrik yaitu menggunakan uji Mann-Whitney U. Hasil perhitungan diperoleh $\mathrm{Z}_{\text {hitung }}=5,47$ dan

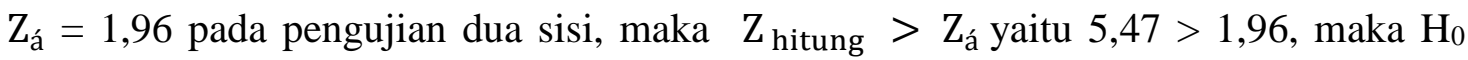
ditolak dan $\mathrm{H}_{\mathrm{a}}$ diterima, artinya terdapat perbedaan hasil belajar kognitif peserta didik yang menggunakan metode pembelajaran team quiz lebih tinggi dibandingkan dengan peserta didik yang menggunakan metode konvensional. Hal tersebut menunjukan bahwa hasil belajar kognitif peserta didik yang menggunakan metode pembelajaran team quiz lebih tinggi dibandingkan dengan peserta didik yang menggunakan metode pembelajaran konvensional dalam pembelajaran Fiqih materi makanan minuman halal dan haram.

Analisis akhir angket motivasi belajar (variabel $\mathrm{Y}_{1}$ ), dilakukan uji signifikansi dengan menggunakan Uji Mann-Whitney U. Hasil perhitungan diperoleh $Z_{\text {hitung }}=$ 6,65 dan $\mathrm{Z}_{a}=1,96$ pada pengujian dua sisi, karena diperoleh $\mathrm{Z}_{\text {hitung }}>\mathrm{Z}_{\text {á }}$ yaitu 6,65 $>$ 1,96, maka $\mathrm{H}_{0}$ ditolak dan $\mathrm{H}_{\mathrm{a}}$ diterima, artinya terdapat perbedaan motivasi belajar peserta didik yang menggunakan metode pembelajaran team quiz dengan peserta didik yang menggunakan metode konvensional. Hal tersebut menunjukan bahwa motivasi belajar peerta didik yang menggunakan metode pembelajaran team quiz lebih tinggi dibandingkan dengan peserta didik yang menggunakan metode pembelajaran konvensional dalam pembelajaran Fiqih materi makanan minuman halal dan haram.

Fungsi motivasi dalam belajar dan pembelajaran antara lain dalam (a) menentukan hal-hal yang dapat dijadikan penguat belajar, (b) memperjelas tujuan belajar yang hendak dicapai, (c) menentukan ragam kendali terhadap rangsangan belajar, (d) menentukan ketekunan belajar (Uno, 2012, p. 27). Karena fungsi motivasi dalam belajar sangatlah penting maka guru harus memperhatikan berbagai hal yang berhubungan dengan motivasi belajar peserta didik, semakin tinggi motivasi belajar peserta didik, makin tinggi peuang berhasil dalam pembelajaran. Sebab pada prinsipnya belajar adalah berbuat, berbuat untuk mengubah tingkah laku menjadi melakukan kegiata (A.M, 2016, p. 96).

Hasil analisis taggapan peserta didik terhadap penerapan metode pembelajaran team quiz (variabel $\mathrm{X}$ ) dalam pembelajaran Fiqih amteri makanan minuman halal dan 
haram yang telah dilaksanakan. Diperoleh persentase rata-rata 81,67\%, hal ini menunjukan tanggapan peserta didik terhadap metode pembelajaran team quiz dalam pembelajaran Fiqih materi makanan dan minuman halal dan haram, berkategori sangat baik.

Keberhasilan proses pembelajaran aktif tidak terlepas dari kemampuan pendidik dalam mengembangkan metode pembelajaran yang berorientasi pada peningkatan intensitas keterlibatan peserta didik dalam proses pembelajaran. penerapan metode yang tepat pada dasarnya bertujuan untuk menciptakan kondisi pembelajaran yang memungkinkan peserta didik dapat belajar secara aktif dan menyenangkan. Melvin L. Silberman mendefinisikan active learning yaitu suatu metode pembelajaran yang mengajak siswa untuk belajar aktif, mereka aktif menggunakan otak, baik untuk menemukan ide pokok dari materi pelajaran, memecahkan persoalan atau mengaplikasikan apa yang baru mereka pelajari ke dalam suatu persoalan yang ada dalam kehidupan nyata (L.Silberman, 2013, p. 9). Mengajukan pertanyaan berarti menunjukkan pola pikir yang dimiliki oleh seseorang, sehingga bertanya dapat juga mendorong kemampuan siswa untuk berpikir (Yamin, 2007, p. 89). Praktiknya, bertanya merupakan suatu bentuk sikap peserta didik untuk dapat mengetahui makna dari suatu hal ataupun suatu masalah sehingga dapat dicari solusi yang tepat dengan begitu peserta didik dapat membangkitkan semangat dan pola pikir kritis, dengan cara yang menyenangkan dalam proses pembelajaran di kelas.

Setelah diterapkan merode pembelajaran team quiz, motivasi belajar dan hasil belajar kognitif peserta didik dalam mengikuti pembelajaran Fiqih lebih meningkat, karena dalam proses pembelajaran, interaksi peserta didik dengan guru, peserta didik dengan peserta didik lainnya lebih terlihat, peserta didik lebih termotivasi dan antusias mengikuti pembelajaran Fiqih dibanding dengan peserta didik yang menggunakan metode konvensional (ceramah), sehingga hasil belajar yang diperoleh peserta didik juga meningkat. Hal tersebut berarti dalam proses pembelajaran peserta didik melakukan proses mendengar, melihat, berdiskusi, serta tanya jawab antara peserta didik dan peserta didik lainnya. Pernyataan tersebut sesuai dengan teori Konfusius dalam Melvin L. Silberman bahwa apa yang saya dengar, saya lupa, apa yang saya lihat, saya sedikit ingat, dan apa yang saya kerjakan, saya pahami (L.Silberman, 2013, p. 23). Ketika semua proses tersebut dilakukan maka peserta didik dapat memahami pelajaran yang mereka pelajari, hal tersebut yang menyebabkan motivasi dan hasil belajar peserta didik kelas eksperimen lebih tinggi daripada peserta didik kelas kontrol. Pembelajaran fiqih dengan menggunakan metode pembelajaran team quiz, memberikan kontribusi yang lebih baik dibanding dengan pembelajaran menggunakan metode konvensional.

Berdasarkan uraian tersebut dapat disimpulkan bahwa pembelajaran Fiqih materi makanan minuman halal dan haram dengan menggunakan metode team quiz, dapat meningkatkan motivasi dan hasil belajar kognitif peserta didik dibandingkan dengan 
menggunakan metode pembelajaran konvensional di kelas VIII MTs Atta'zhimiyah Kota Bandung tahun pelajaran 2017/2018.

\section{SIMPULAN}

Berdasarkan hasil penelitian dan pembahasan serta temuan-temuan yang diperoleh dalam penelitian ini, dapat disimpulkan beberapa hal sebagai berikut:

1. Pelaksanaan pembelajaran fiqih materi makanan dan minuman halal dan haram dengan menggunakan metode pembelajaran team quiz dan metode pembelajaran konvensional di kelas VIII MTs Atta'zhimiyah Kota Bandung, meliputi kegiatan pendahuluan, inti dan penutup.

2. Perbedaan motivasi belajar peserta didik yang menggunakan metode pembelajaran team quiz dengan peserta didik yang menggunakan metode konvensional pada mata pelajaran fiqih materi makanan dan minuman halal dan haram di kelas VIII MTs Atta'zhimiyah kota Bandung, nilai rata-rata motivasi belajar kelas eksperimen sebesar 77,08 sedangkan nilai rata-rata motivasi belajar kelas kontrol sebesar 59,92. Berdasarkan uji signifikansi Mann Whitney $\mathrm{U}$ diperoleh perbedaan yang signifikan nilai $\mathrm{Z}_{\text {hitung }}>$ $\mathrm{Z}_{\alpha}$ yaitu 6,65 > 1,96, maka $\mathrm{H}_{0}$ ditolak dan $\mathrm{H}_{\mathrm{a}}$ diterima.

3. Perbedaan hasil belajar kognitif peserta didik yang menggunakan metode pembelajaran team quiz dengan peserta didik yang menggunakan metode konvensional pada mata pelajaran fiqih materi makanan dan minuman halal dan haram di kelas VIII MTs Atta'zhimiyah Kota Bandung, nilai rata-rata pretest kelas eksperimen sebesar 51,62 dan nilai rata-rata posttest sebesar 83,62 , n-gain pada kelas eksperimen menunjukan peningkatan hasil belajar kognitif peserta didik kelas eksperimen sebesar 0,67 angka tersebut termasuk pada kategori sedang $(0,30<\mathrm{g} \geq 0,70)$. Sedangkan nilai rata-rata pretest kelas kontrol sebesar 52,57 dan nilai rata-rata posttest sebesar 66,48, n-gain pada kelas kontrol menunjukan peningkatan hasil belajar kognitif peserta didik kelas kontrol sebesar 0,29 angka tersebut termasuk pada kategori rendah $(0,30<\mathrm{g} \geq 0,70)$. Berdasarkan uji signifikansi Mann Whitney $\mathrm{U}$ diperoleh perbedaan yang signifikan nilai $\mathrm{Z}_{\text {hitung }}>\mathrm{Z}_{\alpha}$ yaitu 5,47 $>1,96$, maka $\mathrm{H}_{0}$ ditolak dan $\mathrm{H}_{\mathrm{a}}$ diterima.

4. Tanggapan peserta didik terhadap penerapan metode pembelajaran team quiz pada mata pelajaran fiqih materi makanan dan minuman halal dan haram di kelas VIII MTs Atta'zhimiyah Kota Bandung berkategori sangat baik, diperoleh hasil persentase rata-rata $81,67 \%$ dan diinterpretasikan ke dalam skala 100 termasuk kategori sangat baik, karena berada dalam interval $80 \%$ $-100 \%$. 


\section{DAFTAR PUSTAKA}

A.M, S. (2016). Interaksi dan Motivasi Belajar Mengajar. Jakarta: Rajawali Pers. Arifin, Z. (2011). Penelitian Pendidikan. Bandung: Remaja Rosdakarya. Arikunto, S. (2015). Prosedur Penelitian. Jakarta: Rineka Cipta. Daryanto. (2008). Evaluasi Pendidikan. Jakarta: Rineka Cipta. Dzajuli, A. (2005). Ilmu Fiqih. Jakarta: Kencana. Haris, A. J. (2012). Evaluasi Pembelajaran. Yogyakarta: Multi Pressindo.

Hariyanto, W. d. (2012). Pembelajaran Aktif Teori dan Assesmen. Bandung : Remaja Rosdakarya.

Ibrahim, T. (n.d.). Fiqih: Madrasah Tsanawiyah Kelas VIII . Bandung: Armico.

Krathwohl, L. W. (2017). Kerangka Landasan untuk Pembelajaran, Pengajaran dan Asesmen. Yogyakarta: Pustaka Pelajar.

L.Silberman, M. (2013). Active Learning: 101 Cara Belajar Siswa Aktif. Bandung: Nuansa Cendekia.

Makmun, A. S. (2007). Psikologi Kependidikan. Bandung: Remaja Rosdakarya.

Mulyasa, E. (2013). Kurikulum Tingkat Satuan Pendidikan Kemandirian Guru dan Kepala Sekolah. Jakarta: Bumi Aksara.

Nata, A. (2011). Persfektif Islam TEntang Strategi Pembelajaran. Jakarta: Kencana.

Purwanto, N. (2000). Psikologi Pendidikan. Bandung: Remaja Rosda Karya.

PUrwanto, N. (2009). Evaluasi Hasil Belajar. Yogyakarta: Pustaka Pelajar.

Rahaju, R. L. (2014). Kemampuan Komunikasi Matematika Siswa pada Penerapan

Pembelajaran Aktif Strategi Team Quiz Materi Statistika. Jurnal Ilmiah Pendidikan Matematika, 203.

Soemanto, W. (2006). Psikologi Pendiidikan. Jakarta: Rineka Cipta.

Sudjana, N. (2004). Penilaian Hasil Proses Belajar Mengajar . Bandung: remaja Rosda Karya.

Sugiyono. (2010). Metode Penelitian. Bandung: CV Alfabeta.

Syah, M. (2012). Psikoloi Pendidikan. Bandung : Remaja Rosda Karya.

Uno, H. B. (2012). Teori Motivasi dan Pengukurannya. Jakarta: Raja Grafindo Persada. Winkel, W. (2009). Psikologi Pengajaran. Jakarta: Gaung Persada.

Yamin, M. (2007). Kiat Membelajarkan Siswa. Jakarta: Gaung Persada.

Zain, J. B. (1996). Kamus Umum Bahasa Indonesia. Jakarta: Pustaka Sinar Harapan.

Zain, S. B. (2011). Strategi Belajar Mengajar. Jakarta: Rineka Cipta. 